Volume: 14 Issue: 1 Year: 2017

\title{
Effect of group counseling on happiness, life satisfaction and positive-negative affect: A mixed method study ${ }^{1}$
}

\author{
Orkide Bakalım ${ }^{2}$ \\ Arzu Taşdelen Karçkay ${ }^{3}$
}

\begin{abstract}
The aim of this study is to investigate the effects of a group counselling programme on happiness, life satisfaction and positive-negative affect of guidance and psychological counselling department students. The group members consisted of 28 (18 females, 10 males). Group counselling programme was applied once a week for 8 weeks. Quantitative analysis of the study was performed using Wilcoxon Signed Rank Test and qualitative analysis was performed by content analysis of the focus group interviews and student evaluations reports. Quantitative analysis results showed that psychological group counselling enhances the positive emotions, happiness and life satisfaction levels of the students, while it did not have any effect on the negative emotions. Qualitative analysis results demonstrated that students had both personal and professional gains in this process.
\end{abstract}

Keywords: Group counselling; psychodrama; happiness; life satisfaction; mixed-method study.

\section{Introduction}

Attending university is an important life transition. To get away from family and home and to become more independent bring new selection issues, problems and stress for young people (Lovell, Nash, Sharman \& Lane, 2015). Furthemore, adaptation to the university, economic and family related problems, academic achievement concerns, interpersonal and opposite sex relation issues, concerns for the future are some other stressful situations that university students may face (Çivitçi, 2015). These experiences may affect young people's emotions and their outlook on life. Matheny et al. (2002) found that perceived stress is an important predictor of life satisfaction of college students. Despite that, for mental health of individuals emotional awareness is an important feature and it is accepted that there is a positive correlation between emotional awareness and psychological well-being (Kuzucu, 2006). In recent years, another concept on mental health of individuals is subjective well-being (Diener, Suh, Lucas \& Smith, 1999; Y1lmaz \& Arslan, 2013).

According to Diener et al. (1999), components of subjective well-being are pleasant/positive affect (happiness, joy, enthusiasm, ecstasy, satisfaction, pride, affection); unpleasant/negative affect (guilt and shame, melancholy, anxiety, fury, stress, depression, grudge); life satisfaction (desire to change life, satisfaction with current life, satisfaction with the past, satisfaction with future, others' significant views of one's life) and domain satisfactions (work, family, leisure, health, finances, self and one's group). In summary, high level of subjective well-being indicates that the person experience more positive emotion/pleasant effect than negative emotion/unpleasant effect, and have positive cognitive judgements about the quality of his/her own life (Eryllmaz, 2009; Joshanloo

\footnotetext{
1 This article was presented as a oral presentation at the VI. Psychological Counseling and Guidance Applications Congress.

2 Ph.D., Uşak University, Faculty of Education, orkide.akpinar@usak.edu.tr

${ }^{3}$ Ph.D., Akdeniz Univeresity, Faculty of Education, tasdelenarzu@yahoo.com
} 
Bakalım, O., \& Taşdelen Karçkay, A. (2017). Effect of group counseling on happiness, life satisfaction and positivenegative affect: A mixed method study. Journal of Human Sciences, 14(1), 624-632. doi:10.14687/jhs.v14i1.4377

\& Afshari, 2011). This study will focus on three dimensions of subjective well-being. These are happiness, life satisfaction and positive-negative affect.

Happiness is a feeling related to wellbeing, satisfaction and pleasure terms where mainly a positive feeling dominates based on the general evaluation of the life (Moljord, Eriksen, Moksnes \& Espnes, 2011). Another term closely related to happiness but a different one is the life satisfaction, which includes the cognitive evaluation of the individual against his/her life quality considering his/her own criteria. The result of this cognitive evaluation is predominantly the determinant of this cognitive evaluation. Positive feelings are the one giving happiness such as trust, joy, hope while the negative ones are those irritating such as anger, guilt, sadness, and hate (Eryllmaz \& Ercan, 2010).

In recent years, some study results showed that some psychotherapy interventions are successful in enhancing certain aspects of psychological well-being (Weiss et al. 2016). It is known that an atmosphere of trust and self-expression are important sources coping for stressful situations and to enhance well-being (Simons et al. 2002). Group guidance or group counselling is a powerful method of presenting such an atmosphere. Psychological group counselling/group psychotherapy or group training programs are effective to solve the problems which are related to the selfawareness via expressing emotions and needs (Y1lmaz \& Ersever, 2015). Some studies conducted have revealed that psychological group counselling positively affects the wellbeing level of the individuals (Akın, 2009; Albayrak, 2013; Moghanloo, Moghanloo, Babapour-Kheiroddin, Poursharifi \& Pishvaei, 2014; Page \& Chandler, 1994)

Another way of expressing the emotions and needs is the use of psychodrama in psychological group counselling. Psychodrama is an experiential method of group psychotherapy created by Jacob Levy Moreno that uses action techniques to explore the root of psychological and social problems. As an action-oriented or a role-play technique, psychodrama ensures a context in which individuals evaluate habitual patterns of reacting to certain problems and discover alternative ways to respond in a safe and supportive environment (Konopik \& Cheung, 2013). Volunteer group members, as protagonists express their emotions, conflicts or problems through dramatization instead of reporting them. After dramatization, group members can interact with each other and so that people gain insight about themselves and improve their self-expression skills in a safe, supportive environment. (Aytemur et al. 2012; Karataş \& Gökçakan, 2009; Liberali \& Grosseman, 2015).

An important component of counsellor education is experiential experiences. Psychological counselling and guidance students must be aware of the emotions they have against stressful experiences. Because, being helpful to other people requires being aware of their own experiences and feelings. If a psychological counsellor candidate did not participate in a group process as a member, he/she cannot be a group leader (Voltan-Acar, 2001). In Turkey, psychological counsellor candidates take group guidance/counselling skills lessons without passing through such a process. In a study conducted by Pamuk (2012) psychological counsellors reported that they did not manage a psychological counselling group in their institutions after graduation. The inclusion of practical training courses at the university may increase group counselling leadership skills of students. At the same time, group counselling process may contribute to the psychological well-being of the students. The aim of this research is to examine the effect of group counselling on positive-negative affect, happiness and life satisfaction of guidance and psychological counselling students.

\section{Method}

\subsection{Design}

In this study it was used mixed methods and a non-control group pre-test and post-test model which is one of the semi-exprimental desings. A one group pre-test/post-test design examined the effect of an 8 -week group counselling on positive-negative affect, happiness and life 
Bakalım, O., \& Taşdelen Karçkay, A. (2017). Effect of group counseling on happiness, life satisfaction and positivenegative affect: A mixed method study. Journal of Human Sciences, 14(1), 624-632. doi:10.14687/ihs.v14i1.4377

satisfaction of students. Qualitative research was used to describe the experiences of students who participated in group counselling. Thus, a focus group and students' reports analysis were conducted at the end of group process. For quantitative analysis, it was used Wilcoxon signed ranks test for analyzing the meaningfulness of the differences between pre-test and post-test scores.

\subsection{Sample and Setting}

The sample of the study consisted of 28 (18 females, 10 males) third-class Psychological Counselling and Guidance department students of the Uşak University in 2015-2016 academicyears. Group process was planned under the optional psychodrama course. All students volunteered to participate in the group. Group counselling program was arranged once a week for 90 minutes. In the first sessions participants completed scales collecting data about psychological variables. These variables were measured again at 8 weeks after the intervention.

\subsection{Group Counselling Intervention}

Group counselling program consisted of eight sessions. In the process of psychological group counselling, psychodrama techniques were employed and sessions were held as follows:

Each session started with group interaction. During this process, the previous session was reminded and group members talked about them. Later, warm-up games were played to facilitate expression of feelings. In each session, after the interaction and warm-up process, volunteer students came on scene one by one and shared their problems, experiences or dreams through roleplaying as a protagonist. During the role-playing, the scene revived with the help of other group members chosen by protagonist. Following the protagonist-based games, group interaction started and group members gave feedbacks about the game and their feelings about it. Finally, the sessions ended by making summary and general evaluation.

\subsection{Instruments}

Positive and Negative Affect Schedule (PANAS): The PANAS (Watson et al., 1988) consisted of 20 -item affective expressions which are 10 positive (PA) and 10 negative (NA). Turkish adaptation study was carried out by Gençöz (2000). Cronbach's alpha of the PA sub-scale was found .83 ; NA .86, and test-retest reliability for each was $r=.45$ and $r=.54$, respectively. Criterionrelated validity was determined by examining the relations between the Beck Depression Scale and the Beck Anxiety Scale. The correlation coefficients were -.48 and -.22 for PA, .51 and .47 for NA.

The Oxford Happiness Questionnaire Short Form (OHQ-SF): The OHQ-SF (Hills \& Argyle, 2002) consisted of eight items measure of happiness. Turkish Adaptation of scale was carried out by Doğan \& Akınc1-Çötok (2011). In this adaptation study, internal consistency coefficient and test-retest reliability coefficient were determined to be .74 and .85 , respectively.

Life Satisfaction Scale (LSS): Turkish adaptation of scale was done by Köker (1991). The LSS was measured with the Satisfaction with Life Scale which was developed by Dienner, Emmons, Laresen and Friffin (1985) and adapted to Turkish by Köker (1991), consists of five Likert-type items regarding life satisfaction, with answers ranging from "strongly disagree" (1) to "strongly agree" (7). Köker (1991) previously determined that the scale's test-retest consistency coefficient at a three-week interval was $r=.85$ and that its item-test correlation ranged from $r=.71$ to $r=.80$. The internal consistency coefficient was .76 (Köker, 1991). In this study, Cronbach's alpha and testretest reliability were found .76 and .85 , respectively. 
Bakalım, O., \& Taşdelen Karçkay, A. (2017). Effect of group counseling on happiness, life satisfaction and positivenegative affect: A mixed method study. Journal of Human Sciences, 14(1), 624-632. doi:10.14687/ihs.v14i1.4377

\section{Results}

\subsection{Quantitative Analysis}

In this study given the fact that the data do not have a normal distribution and that the number of study group was below 30, a non-parametric analysis Wilcoxon Signed Rank Test was used to compare pre-test and post-test results.

Table 1. Results of Wilcoxon Signed Rank Test (One group- Pre-test-Post-test)

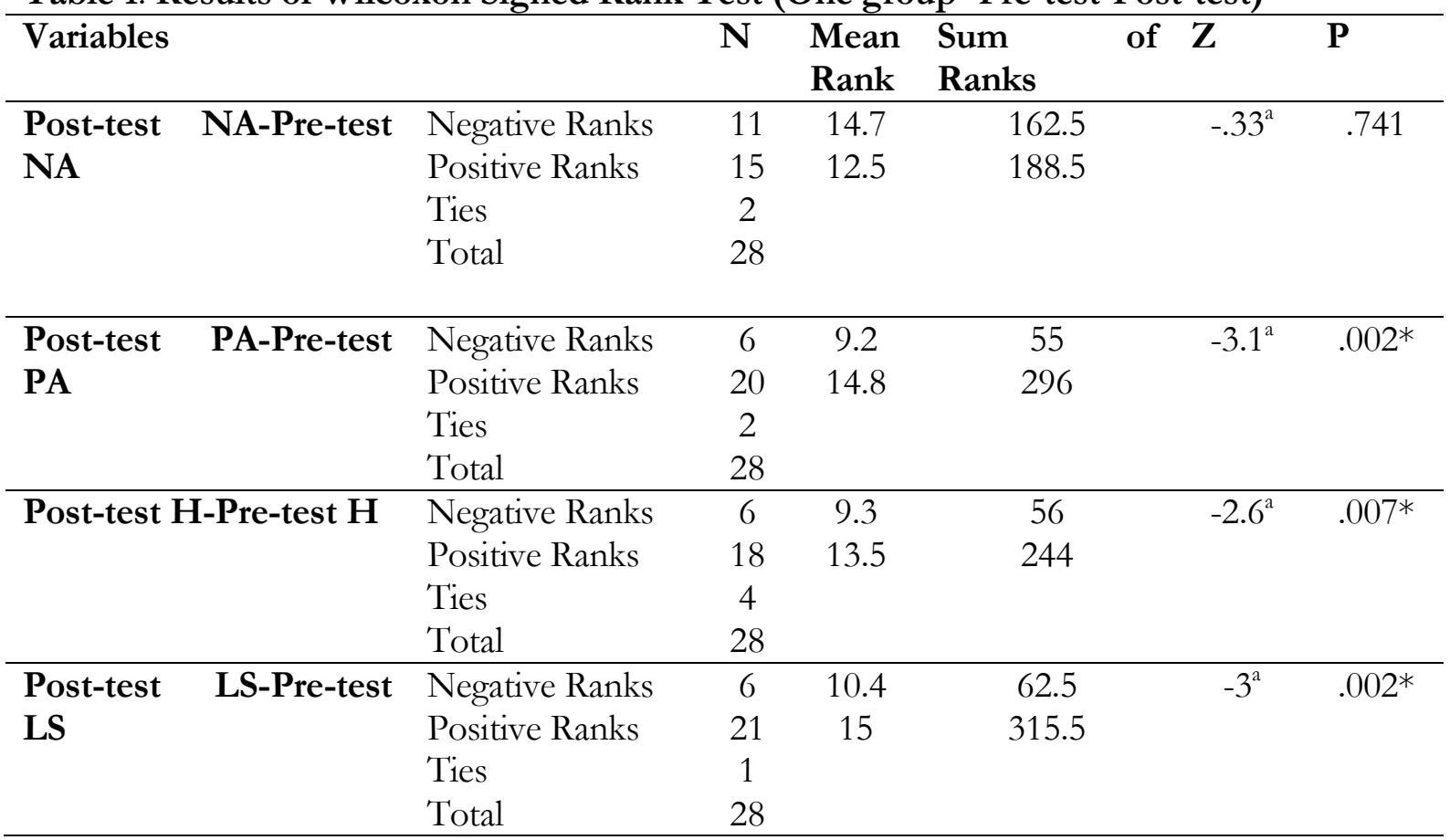

NA= Negative affect, PA=Positive affect, $\mathrm{H}=$ Happiness, LS=Life Satisfaction

a. Based on negative ranks

${ }^{*} \mathrm{p}<.01$

Table 1 shows that there were significant differences between positive affect $(z=-3.1, p<$ $.01)$, happiness $(z=-2.6, p<01)$ and life satisfaction $(z=-3, p<.01)$ pre-test and post-test scores. But, there was no significant difference $s$ between negative affect $(z=-.33, p>.01)$ pre-test and post-test scores.

\subsection{Qualitative Analysis}

\subsubsection{Focus Group Interviews and Student Reports}

In the last session, the students evaluated the group process writing a report. After the session, the focus group interview was conducted. Participants in the focus group included 8 girls and 4 boys. Group questions were designed to understand the group members' attitudes towards group process. Focus group lasted approximately 40 minutes. Discussions were audio-recorded and transcribed verbatim. As a result of reading the transcripts and students reports, some codes were assigned and major and sub-themes were identified.

Consequently 3 major themes emerged as data were analyzed: (1) Gains: a-personal and bprofessional; (2) Deficiencies and (3) Suggestions. 
Bakalım, O., \& Taşdelen Karçkay, A. (2017). Effect of group counseling on happiness, life satisfaction and positivenegative affect: A mixed method study. Journal of Human Sciences, 14(1), 624-632. doi:10.14687/jhs.v14i1.4377

\section{Gains}

\section{a. Personal Gains}

Majority of the participants stated that hearing similar experiences from others during the psychodrama process relieved them, their skills to express themselves improved, their awareness and creativeness developed, they started to rely on their friends more, and learned not to be prejudicial against their friends.

"It is absolute that this was a good experience. This course contributed a lot to me. An incredible experience. The greatest idea (lesson) I have learned out of this experience is not to have prejudices for someone. You have the chance to share your experiences with someone you don't know. Many people with a lack of communication must have this experience". (Ayse, 21, personal communication)

"Students with a self-disclosure have stated all positive and negative feelings, therefore this caused a more trust in the group and, as I said before, allowed people to relieve. When other students witnessed this trust environment and warm class atmosphere, they have participated more actively in other courses according to my observations" (Onur, 22, personal communication).

\section{b. Professional Gains}

The participants reported during this process that they had the chance to observe the psychological counselling process with the group before managing a group; they improved on their profession upon combination of the theory and practice, learned warm-up games, and gained psychological counselling skills as well as helping others and developing empathy.

"After psychodrama, I began to love my department more and pay more value, and have a greater belief in my profession, started to embrace it. I saw the reasons behind the behaviours. This awareness contributes to people a lot. I desired to apply these practices into my future professional life and enbance their well-being. I am impatiently waiting to ensure them that they can also be aware of their own feelings, ideas and behaviours and be a person helping them in this regard". (Seyhan, 21, personal communication)

"Psychological group counselling has contributed a lot to my professional skills. I have learned the psychological group counselling example and I have knowledge on how to apply the process. I have realized that I am more comfortable in developing empathy with my friends while observing them and my eagerness to help them has enhanced". (Deniz. 21, personal communication).

\section{Deficiencies}

The participants stated that the duration and number of sessions are not enough and the fact that group members used to know each other prevented revealing the ideas easily. Furthermore, lack of necessary materials has become a deficit because not enough theoretical information was conveyed in addition to practice.

"The high number of participants caused creating two psychodrama groups. Therefore, two groups shared the course duration in half. Time flows fast during psychodrama and a process which you never want to finish develops" (Aræu, 21, personal communication).

"Because it is a group established under a course, it consists of the same class members. And this prevents the confidentiality of the information and revealing opinions" (Ŭgur, 21, personal communication).

\section{Suggestions}

The participant recommended that the group process should be longer, should not be under the scope of course only, it should be sustained under a title such as psychodrama club, and relevant material should be provided for the group (carpet, toys, costumes). 
Bakalım, O., \& Taşdelen Karçkay, A. (2017). Effect of group counseling on happiness, life satisfaction and positivenegative affect: A mixed method study. Journal of Human Sciences, 14(1), 624-632. doi:10.14687/jhs.v14i1.4377

"Not about the hardships, but... I wish there were another group study and people we don't know joined us. We would know new people and test how we behave when we are together with foreign people" (Can, 21, personal communication).

"A drama club not only for the courses but for everyone should be available and this should be sustained" (Alp, 21, personal communication).

\section{Discussion}

This study examined the effects of psychological counselling process, where 8 session psychodrama methods were used, on positive-negative affect, happiness and life satisfaction of the psychological guidance and counselling students. Quantitative results showed that psychological group counselling enhances the positive emotions, happiness and life satisfaction levels of the students, while it did not have any effect on the negative emotions. Psychological group counselling ensures a reliable and supportive environment to allow the individuals express their feelings and contributes to development of students' mental health by means of improving positive feelings such as happiness, optimism, self-respect, and well-being (Gürgan, 2013; Karataş, 2014; Li, Su \& Zhang, 2003). As a consequence of recovery on these feelings, an increase in the life satisfaction is also an expected output. On the other hand, no effect of group life was detected on the negative feelings of the students. The grounds of the negative feelings may go deeper and 8 session process might not have been sufficient to touch them, however, because the members knew each other beforehand may have forced them not to reveal their actual feelings easily.

Qualitative analysis results demonstrated that students had both personal and professional gains in this process. Self-expressions skills, increase in trust issues, improvement on awareness and creativeness are some of the personal gains of the group members. Psychodrama is a strong method supporting spontaneity and awareness, as well as contributing the self-expression skills (Aytemur et al. 2012; Liberali \& Grosseman, 2015). Moreover, it provides an important social support environment for individuals (İren-Akbiyık, Soygür \& Karabulut, 2012). Considering the professional gains, it was firstly signified that the students should have the chance of experiencing and observing the psychological group counselling. It is an important part of this training that the students of psychological guidance and counselling students should experience such a process before starting the psychological group counselling (Voltan-Acar, 2001). On the other hand, the deficiencies based on the qualitative results were discussed in the result and suggestions part.

This study was conducted by psychodrama techniques in the psychological group counselling process. Psychodrama is a good self-expression method appropriate to development processes of individuals and a strong method in recovering the mental illnesses as well as studying the objects related to the human relations (Albayrak, 2013). Studies showed that psychodrama group therapy reduced level of depression, negative automatic thoughts, and dysfunctional attitudes (Hamamc1, 2006); aggression (Karataş, 2011; Karataş \& Gökçakan, 2009); internalizing symptoms (Nazar et al. 2014), anxiety (Karataş, 2009), hopelessness (Karataş, 2014) while it increased problem solving and conflict resolution skills (Karataş, 2011), perceived social support (İren-Akbiyık, Soygür \& Karabulut, 2012) and well-being level (Karataş, 2014). Accordingly, it is considered that using the psychodrama techniques in the psychological group counselling process allows the group members to easily express themselves and thereby contributes to their well-being, and this makes the process more effective. 
Bakalım, O., \& Taşdelen Karçkay, A. (2017). Effect of group counseling on happiness, life satisfaction and positivenegative affect: A mixed method study. Journal of Human Sciences, 14(1), 624-632. doi:10.14687/jhs.v14i1.4377

\section{Limitations Result and Suggestions}

The 8 session psychological group counselling conducted in this research was held under a selective course in a term. The duration and number of sessions were found to be inadequate by the students. The practical courses in the psychological guidance and counselling field should be continuous instead of limiting one term. Additionally, suitable place and materials should be provided for this kind of courses. No control group was created in this research. Repeating the same study with a control group may provide different outputs on the efficiency of the psychological group counselling. On the other hand, this study was conducted with psychological guidance and counselling students. It was not able to be controlled whether the change in the group students was related to other field courses or not. Repeating the study with other students in other faculties may better show the impacts of psychological group counselling. Furthermore, psychodrama techniques were used in the psychological group counselling process of this study. It was not tested whether use of these techniques were effective in the change of students. Carrying out new research designs in which psychological group conselling processes utilizing and not utilizing these techniques may clarify the issue. Furthermore, increasing the number of studies on psychological group counselling based on different variables would present significant contributions to theoretical and practical sides of the psychological counselling field.

\section{References}

Akın, A. (2009). Akılcı-duygusal davranışçı terapi (SDDT) odaklı grupla psikolojik danışmanın iyi olma ve özduyarlık üzerindeki. Yayınlanmamış Doktora Tezi, Sakarya Üniversitesi, Sosyal Bilimler Enstitüsü, Sakarya.

Albayrak, G. (2013). Psiko-eğitim programı ile psikodramanın üniversite öğrencilerinin psikolojik iyi oluşlanına etkisinin karşılaştırılması. Yayınlanmamış Doktora Tezi, Mersin Üniversitesi, Eğitim Bilimleri Enstitüsü, Mersin.

Aytemur, Z. A., Pişmişoğlu, B., Kılınç, O., Pişmişoğlu, E., Hacıevliyagil, S. S., \& Karaman, C. (2012). Intensive clinic intervention plus psychodrama in smoking cessation and effects on cessation outcome. Turkiye Klinikleri Journal of Medical Sciences, 32(3), 630-637. doi:10.5336/medsci.2011-23965

Çivitçi, A. (2015). The Moderating Role of Positive and Negative Affect on the Relationship between Perceived Social Support and Stress in College Students. Educational Sciences: Theory and Practice, 15(3), 565-573.

Diener, E. D., Emmons, R. A., Larsen, R. J., \& Griffin, S. (1985). The satisfaction with life scale. Journal of Personality Assessment, 49(1), 71-75. doi:10.1207/s15327752jpa4901_13

Diener, E., Suh, E. M., Lucas, R. E., \& Smith, H. L. (1999). Subjective Weil-Being: Three Decades of Progress. Psychological Bulletin, 125(2), 276-302.

Doğan, T., \& Akıncı-Çötok, N. (2011). Oxford mutluluk ölçeği kısa formunun Türkçe uyarlaması: Geçerlik ve güvenirlik çalışması. Türk Psikolojik Damışma ve Rebberlik Dergisi, 4(36), 165-170.

Eryllmaz, A. (2009). Ergen öznel iyi oluş ölçeğinin geliştirilmesi. Türk Ĕ̈itim Bilimleri Dergisi, 7(4), 975-989.

Gençöz, T. (2000). Pozitif ve negatif duygu ölçeği: Geçerlik ve güvenirlik çalışması. Türk Psikoloji Dergisi, 15(46), 19-26.

Gürgan, U. (2013). The effect of psychological counselling in group on life orientation and loneliness levels of the university students. Educational Research and Reviews, 8(24), 2303-2312. doi: 10.5897/ERR2013.1613

Hamamci, Z. (2006). Integrating psychodrama and cognitive behavioral therapy to treat moderate depression. The Arts in Psychotherapy, 33(3), 199-207. doi: 10.1016/j.aip.2006.02.001 
Bakalım, O., \& Taşdelen Karçkay, A. (2017). Effect of group counseling on happiness, life satisfaction and positivenegative affect: A mixed method study. Journal of Human Sciences, 14(1), 624-632. doi:10.14687/jhs.v14i1.4377

Hills, P. ve Argyle, M. (2002). The Oxford Happiness Questionnaire: a compact scale for the measurement of psychological well-being. Personality and Individual Differences, 33, 1073-1082. Doi: 10.1016/S0191-8869(01)00213-6

İren-Akbiyık, D., Soygür, H. \& Karabulut, E. (2012). Psiko-onkoloji ve aile hekimliğinde ruh sağllğını güçlendirme: Sosyal destek alg1s1 ve psikodrama grup terapisi uygulamaları. Anatolian Journal of Psychiatry/ Anadolu Psikiyatri Dergisi, 13(3), 205-209.

Joshanloo, M., \& Afshari, S. (2011). Big five personality traits and self-esteem as predictors of life satisfaction in Iranian Muslim university students. Journal of Happiness Studies, 12(1), 105113.doi: 10.1007/s10902-009-9177-y

Karataş, Z. (2009). Psikodrama ile yapılan grup çalışmasının ergenlerin sürekli kaygı düzeylerine etkisi. Căgdaş Ë̆itim Dergisi, 34(360), 31-37.

Karatas, Z., \& Gökcakan, Z. (2009). A Comparative Investigation of the Effects of CognitiveBehavioral Group Practices and Psychodrama on Adolescent Aggression. Educational sciences: Theory and practice, 9(3), 1441-1452.

Karatas, Z. (2011). Investigating the Effects of Group Practice Performed Using Psychodrama Techniques on Adolescents' Conflict Resolution Skills. Educational Sciences: Theory and Practice, 11(2), 609-614.

Karataş, Z. (2014). Psikodrama Uygulamasının Üniversite Öğrencilerinin Öznel İyi Oluş ve Umutsuzlukları Üzerindeki Etkisi. Eğitim ve Bilim, 39(173).

Konopik, D. A., \& Cheung, M. (2013). Psychodrama as a social work modality. Social work, 58(1), 920. doi: $10.1093 / \mathrm{sw} / \mathrm{sws} 054$

Kuzucu, Y. (2006). Duyguları fark etmeye ve ifade etmeye yönelik bir psikoeğitim programının, üniversite öğrencilerinin duygusal farkındalık düzeylerine, duyguları ifade etme eğilimlerine, psikolojik ve öznel iyi oluşlarına etkisi. Yayınlanmamıs Doktora Tezi, Ankara Üniversitesi, Ankara.

Liberali, R., \& Grosseman, S. (2015). Use of Psychodrama in medicine in Brazil: a review of the literature. Interface-Comunicação, Saúde, Educação, 19(54), 561-571. doi: 10.1590/180757622014.0524

Köker, S. (1991). Normal ve sorunlu ergenlerin yaşam doyumu düzeyinin karşılaştırılması [Comparison of the level of life satisfaction of normal adolescents and adolescents with problems]. Unpublished master's dissertion, Ankara University, Ankara, Turkey.

Lee, D. S., \& Padilla, A. M. (2016). Predicting South Korean university students' happiness through social support and efficacy beliefs. International Journal for the Advancement of Counselling, 38(1), 48-60. doi: 10.1007/s10447-015-9255-2

Lovell, G. P., Nash, K., Sharman, R., \& Lane, B. R. (2015). A cross-sectional investigation of depressive, anxiety, and stress symptoms and health-behavior participation in Australian university students. Nursing \& bealth sciences, 17(1), 134-142. doi: 10.1111/nhs.12147

Matheny, K. B., Curlette, W. L., Aysan, F., Herrington, A., Gfroerer, C. A., Thompson, D., \& Hamarat, E. (2002). Coping resources, perceived stress, and life satisfaction among Turkish and American university students. International Journal of Stress Management, 9(2), 81-97. doi: 10.1023/A:1014902719664

Moghanloo, R. A., Moghanloo, V. A., Babapour-Kheiroddin, J., Poursharifi, H., \& Pishvaei, M. (2014). The effect of Group Hope Therapy on subjective wellbeing, acceptance and rumination in HIV+ patients. Journal of Kermanshah University of Medical Sciences (J Kermanshah Univ Med Sci), 18(5), 265-274

Moksnes, U. K., \& Espnes, G. A. (2013). Self-esteem and life satisfaction in adolescents-gender and age as potential moderators. Quality of Life Research, 22(10), 2921-2928.doi: $10.1007 / \mathrm{s} 11136-013-0427-4$ 
Bakalım, O., \& Taşdelen Karçkay, A. (2017). Effect of group counseling on happiness, life satisfaction and positivenegative affect: A mixed method study. Journal of Human Sciences, 14(1), 624-632. doi:10.14687/ihs.v14i1.4377

Moljord, I. E. O., Eriksen, L., Moksnes, U. K., \& Espnes, G. A. (2011). Stress and happiness among adolescents with varying frequency of physical activity. Perceptual and Motor Skills, 113(2), 631-646. doi: 10.2466/02.06.10.13.PMS.113.5.631-646

Nazar, F. J., Zare-Bahramabadi, M., Delavar, A., \& Gilan, N. R. (2014). Efficacy of psychodrama techniques in internalizing symptoms(anxiety, depression and somatization) among adolescent girls victims of bullying in Kermanshah. Journal of Mazandaran University of Medical Sciences, 24, 142-148.

Page, R. C., \& Chandler, J. (1994). Effects of group counseling on ninth-grade at-risk students. Journal of Mental Health Counseling. 16 (3), 340-351.

Pamuk, M. (2012). Psikolojik danışmanların psikolojik danışma uygulamalarına ve uygulamada kendi yeterliklerine ilişkin algıları. Yayımlanmamış Doktora Tezi, İnönü University, Malatya, Turkey.

Simons, C., Aysan, F., Thompson, D., Hamarat, E., \& Steele, D. (2002). Coping resource availability and level of perceived stress as predictors of life satisfaction in a cohort of Turkish college students. College Student Journal, 36(1), 129-142.

Voltan-Acar, N. (2001). Grupla psikolojik danışma ilke ve teknikleri. Ankara: Nobel Yayın Dağıtım.

Weiss, L. A., Westerhof, G. J., \& Bohlmeijer, E. T. (2016). Can We Increase Psychological WellBeing? The Effects of Interventions on Psychological Well-Being: A Meta-Analysis of Randomized Controlled Trials. PloS one, 11(6), e0158092. doi:10.1371/journal.pone.0158092.

Yllmaz, H., \& Arslan, C. (2013). Subjective well-being, positive and negative affect in Turkish university students. Online Journal of Counseling \& Education, 2(2), 1-8.

Yilmaz, D., \& Ersever, O. G. (2015). The Effects of the Anger Management Program and the Group Counseling on the Anger Management Skills of Adolescents. Online Journal of Counseling \& Education, 4(4), 16-34. 